\title{
Autophagy Promoted Neural Differentiation of Human Placenta-derived Mesenchymal Stem Cells
}

\author{
AREECHUN SOTTHIBUNDHU ${ }^{1}$, PATTAMON MUANGCHAN ${ }^{2}$, RUCHEE PHONCHAI $^{2}$, \\ WILASINEE PROMJANTUEK ${ }^{2}$, NIPHA CHAICHAROENAUDOMRUNG ${ }^{2}$, \\ PHONGSAKORN KUNHORM ${ }^{2}$ and PARINYA NOISA ${ }^{2}$ \\ ${ }^{1}$ Chulabhorn International College of Medicine, Thammasat University, Pathum Thani, Thailand; \\ ${ }^{2}$ Laboratory of Cell-Based Assays and Innovations, School of Biotechnology, \\ Institute of Agricultural Technology, Suranaree University of Technology, Nakhon Ratchasima, Thailand
}

\begin{abstract}
Background/Aim: Human placenta-derived mesenchymal stem cells (hPMSCs) are multipotent and possess neurogenicity. Numerous studies have shown that Notch inhibition and DNA demethylation promote neural differentiation. Here, we investigated the modulation of autophagy during neural differentiation of hPMSCs, induced by DAPT and 5-Azacytidine. Materials and Methods: hPMSCs were treated with DAPT to induce neural differentiation, and the autophagy regulating molecules were used to assess the impact of autophagy on neural differentiation. Results: The hPMSCs presented with typical mesenchymal stem cell phenotypes, in which the majority of cells expressed CD73, CD90 and CD105. hPMSCs were multipotent, capable of differentiating into mesodermal cells. After treatment with DAPT, hPMSCs upregulated the expression of neuronal genes including SOX2, Nestin, and BIII-tubulin, and the autophagy genes LC3I/II and Beclin. These genes were further increased when 5-Azacytidine was co-supplemented in the culture medium. The inhibition of autophagy by chloroquine impeded the neural differentiation of hPMSCs, marked by the downregulation of BIII-tubulin, while the activation of autophagy by valproic acid (VPA) instigated the emergence of BIII-tubulin-positive cells. Conclusion: During the differentiation process, autophagy was modulated, implying that autophagy could play a significant role during the differentiation of these cells. The blockage and stimulation of
\end{abstract}

This article is freely accessible online.

Correspondence to: Parinya Noisa, Ph.D., School of Biotechnology, Institute of Agricultural Technology, Suranaree University of Technology, Nakhon Ratchasima 30000, Thailand. Tel: +66 44223393, Fax: +66 44224154, e-mail: p.noisa@sut.ac.th

Key Words: Human placenta, mesenchymal stem cells, neural differentiation, notch signaling, autophagy. autophagy could either hinder or induce the formation of neural-like cells, respectively. Therefore, the refinement of autophagic activity at an appropriate level might improve the efficiency of stem cell differentiation.

Stem cell technology is promising for manipulating human illnesses in terms of disease modeling, tissue engineering, drug discovery and cell therapy (1). One major issue in embryonic stem cell (ESC) research is safety and the ethical issues surrounding this area. In this regard, many groups have made an attempt to identify and characterize adult stem cells (ASCs) for future therapies (2). The best characterized ASC populations reside in the bone marrow (BM). BM-derived mesenchymal stem cells (MSCs) are considered to be a potential source for stem cell therapies due to their plasticity and potent immunosuppressive capabilities (3). Despite their capacity and potency, the difficulty in obtaining BM aspirates from patients is a problem; hence, alternative sources of therapeutic MSCs have been sought. Among many types of stem cells, human placenta tissue has gained increasing attention as an attractive source of adult stem cells, as they are considered medical waste, non-invasive and easy to isolate $(4,5)$. Human placental-derived mesenchymal stem cells (hPMSCs) contain a great potential to differentiate into various cells types, including neuronal cells (6). Numerous studies have shown success in differentiating hPMSCs towards the neural lineage under specific conditions $(7,8)$. Therefore, neural differentiation from hPMSCs provides a promising cell-based therapy for neurodegenerative diseases, such as Alzheimer's, Parkinson's and Huntington's disease.

In this study, we focus on the Notch signaling which has a critical role for directing differentiation of stem cells into several cell types (9-11). Notch signaling is activated when Notch receptor binds to its ligand, and results in the cleavage of the Notch intracellular domain (NICD) of the Notch receptor. NICD can then translocate into the nucleus and initiate the transcription of Notch target genes $(12,13)$. One 
of the most significant approaches for directing cell reprograming is applying the small chemical molecules at various targets of cell regulation pathways. Recent developments in neural differentiation have heightened the need for the inhibition of Notch signaling pathway by $\gamma$ secretase inhibitors such as DAPT, which was shown to induce neural differentiation (14-16). In this study, we set out to differentiate harvested hPMSCs toward the neural lineage using a combination of small molecules of differentiation protocols originally designed for hPMSCs. There is a solid connection between epigenetic modifiers and the changes in gene expression profiles during stem cell differentiation (17). DNA demethylating agents can inhibit methylation at gene promotes which is possibly a prerequisite for transcription activation. 5-Azacytidine is a commonly used DNA demethylation compound, which can integrate into DNA and inhibit DNA methylation $(18,19)$. The combination of DAPT and 5-Azacytidine might thus particularly impact neural differentiation of hPMSCs.

Autophagy is a key mechanism involved in cell selfrenewal, cell differentiation, and embryonic development, and acts as cellular cleaning process to get rid of invading microorganisms and toxic aggregated proteins. Autophagy is initiated by the formation of double-membrane-bound vesicles, called autophagosomes, which then fuse with lysosomes to enable the degradation of autophagic cargos and the subsequent recycling of nutrients and membranes (20). Recent evidence suggests that autophagy is known as an important event for stem cell differentiation, for instance the differentiation of muscle stem cells, mesenchymal stem cells, and human induced pluripotent stem cell (iPSCs) (2123). To date, there has been limited explorations the roles of autophagy during neural differentiation of human mesenchymal stem cells using small molecules. As no definitive proof is available, it is substantial to have a clear understanding on the neural differentiation process of hPMSCs by targeting Notch signaling and the modified levels of autophagy. In this study, we induced hPMSCs towards the neural lineage by DAPT and 5-Azacytidine and observed the effect of autophagy modulation during hPMSCs differentiation.

\section{Materials and Methods}

Isolation and cultivation of hPMSCs. Human placental tissues were collected from healthy donors with written informed consent from the Suranaree University of Technology Hospital (SUTH, Nakhon Ratchasima, Thailand). The protocol was approved by the ethics committee of Suranaree University of Technology. The human placental tissues were isolated and cultured according to the guidelines from the previous report with some modification (24) Briefly, placental tissue was minced into small pieces and placed in a dish with $4 \mathrm{mg} / \mathrm{ml}$ collagenase/dispase (Roche, Germany) to digest at $37^{\circ} \mathrm{C}$ for $1 \mathrm{~h}$. Digested tissues were maintained in medium containing Dulbecco's Modified Eagle Medium high glucose (DMEM/HG; Hyclone, Logan, UT, USA), supplemented with 20\% (v/v) fetal bovine serum (FBS; Gibco BRL, Grand Island, NY, USA), $1 \mathrm{mM}$ L-glutamine, $1 \mathrm{mM}$ Minimal essential medium (MEM; Sigma-Aldrich, St. Louis, MO, USA), 100 U/ml Penicillin and $100 \mathrm{~g} / \mathrm{ml}$ Streptomycin (Sigma-Aldrich). hPMSCs were incubated at $37^{\circ} \mathrm{C}$, in $5 \% \mathrm{CO}_{2}$ for 7 to 14 days. The medium was replaced every 3 days until fibroblast-like cells migrated out from the placental tissues. hPMSCs were maintained and passaged when reaching 90-100\% confluence, and 3 independent lines of hPMSCs were used for all experiments.

Characterization of hPMSCs. hPMSCs were seeded approximately at a density of $2 \times 10^{4}$ cells/well on a 6 -well culture plate (Nunc, Roskilde, Denmark), coated with Geltrex basement membrane (Gibco). For osteogenic induction, hPMSCs were cultured in osteogenic induction medium, consisting of DMEM, 10\% FBS, 100 $\mathrm{nM}$ dexamethasone, $0.2 \mathrm{mM}$ L-ascorbate-2-phosphate and $10 \mathrm{mM}$ $\beta$-glycerophosphate (Sigma-Aldrich). The medium was changed every other day for 21 days. Cells were fixed with $4 \%$ paraformaldehyde (PFA) for 15 min and stained with Alizarin Red (Sigma-Aldrich) to detect the bone matrix mineralization. To induce adipogenic differentiation, cells were induced by $10 \mu \mathrm{g} / \mathrm{ml}$ insulin, $60 \mu \mathrm{M}$ indomethacin, $0.5 \mu \mathrm{M}$ hydrocortisone and $0.5 \mathrm{mM}$ isobutyl methylxanthine (IBMX) for 21 days. Cells were then fixed and lipid droplets were stained by Oil Red O (Sigma-Aldrich). For chondrogenic differentiation, hPMSCs were induced by ITS-plus premix (BD Biosciences, San Jose,CA) at a concentration of 6.25 $\mu \mathrm{g} / \mathrm{ml}$ insulin, $6.25 \mu \mathrm{g} / \mathrm{ml}$ transferrin and $6.25 \mathrm{ng} / \mathrm{ml}$ selenious acid. Additionally, $50 \mu \mathrm{g} / \mathrm{ml}$ ascorbate 2-phosphate, $40 \mu \mathrm{g} / \mathrm{ml} \mathrm{L}$-proline, $100 \mu \mathrm{g} / \mathrm{ml}$ sodium pyruvate, $100 \mathrm{nM}$ dexamethasonee and $10 \mathrm{ng} / \mathrm{ml}$ TGF- $\beta 3$ were also added. After 21 days, chondrocytes were stained with Alcian Blue (Sigma-Aldrich).

Flow cytometry analysis. hPMSCs were collected and washed twice in phosphate-buffered saline (PBS) and resuspended at a concentration of $1 \times 10^{6}$ cells $/ \mathrm{ml}$. $10 \mu \mathrm{l}$ of the detecting antibody was added to $100 \mu \mathrm{l}$ of the cell suspension. Fluorescence-conjugated antibodies against CD73, CD105, CD90, CD34 and CD45 (Biolegend, San Diego, CA, USA) were incubated with cells at $37^{\circ} \mathrm{C}$ for $30 \mathrm{~min}$. Cells were the analyzed using a FACS Calibur instrument and CellQuest Pro software version 3.3 (BD Biosciences, San Jose, CA, USA).

Differentiation of hPMSCs into neural-like cells. hPMSCs were seeded at a density of $2 \times 10^{4}$ cells/well onto a 6-well plate (Nunc), coated with Geltrex (Gibco). Neural differentiation was induced by the induction medium, containing Neurobasal (NB) medium (Gibco), DMEM/F12 (Hyclone), N2 supplement (100X, Gibco), and $10 \mu \mathrm{M}$ of retinoic acid (Gibco). In addition, neural differentiation was performed by a 3-step protocol. Firstly, the induction medium was supplemented with DAPT at various concentrations $(0,5,10$ and $20 \mu \mathrm{M}$ ) for 7 days. Then, $10 \mu \mathrm{M}$ 5-Azacytidine (Sigma-Aldrich) was added in the induction medium with $10 \mu \mathrm{M}$ DAPT for another 7 days. Finally, either $10 \mu \mathrm{M}$ VPA or $10 \mu \mathrm{M}$ chloroquine was supplemented into the differentiation medium, that already included $10 \mu \mathrm{M}$ of DAPT and $10 \mu \mathrm{M}$ of 5-Azacytidine. Differentiated cells were collected at day 1,5 and 7 for RT-PCR gene expression analysis and cell morphology was observed by a phase-contrast microscope. 
Table I. Primer sequence information for RT-PCR.

\begin{tabular}{|c|c|c|}
\hline Gene & Primer sequence $\left(5^{\prime} \rightarrow 3^{\prime}\right)$ & Length (bp) \\
\hline GAPDH & $\begin{array}{l}\text { Forward: 5'- TCACCACCACGGCCGAGCG -3' } \\
\text { Reverse 5'- TCTCCTTCTGCATCCTGTCG-3' }\end{array}$ & 351 \\
\hline$\beta$ III-tubulin & $\begin{array}{l}\text { Forward: 5'-GCTCAGGGGCCTTTGGACATCTCTT-3', } \\
\text { Reverse 5'-TTTTCACACTCCTTCCGCACCACATC-3' }\end{array}$ & 148 \\
\hline NESTIN & $\begin{array}{l}\text { Forward: 5'- CAGCTGGCGCACCTCAAGATG-3' } \\
\text { Reverse 5'- AGGGAAGTTGGGCTCAGGACTGG-3' }\end{array}$ & 209 \\
\hline SOX2 & $\begin{array}{l}\text { Forward: 5'- CCCCCGGCGGCAATAGCA-3', } \\
\text { Reverse 5'- TCGGCGCCGGGGAGATACAT -3' }\end{array}$ & 448 \\
\hline LC3I/II & $\begin{array}{c}\text { Forward: 5'- CTTCGCCGACCGCTGTAA -3' } \\
\text { Reverse 5'- GGTGCCTACGTTCTGATCTGT G -3, }\end{array}$ & 261 \\
\hline BECLIN & $\begin{array}{l}\text { Forward: 5'- GCT CAG TACCAGCGAGAATA -3' } \\
\text { Reverse 5'- GTC AGGACTCC AGA TAC GA -3' }\end{array}$ & 350 \\
\hline GAD1 & $\begin{array}{l}\text { Forward: 5'- GTCGAGGACTCTGGACAGTA -3' } \\
\text { Reverse 5'- GGAAGCAGATCTCTAGCAAA -3' }\end{array}$ & 357 \\
\hline
\end{tabular}

Immunocytochemistry. Cells were washed with $3 \mathrm{X}$ PBS, and fixed with 4\% PFA for $15 \mathrm{~min}$. Then, the cells were incubated in blocking buffer, which included $4 \%$ bovine serum albumin (BSA; SigmaAldrich) and $0.5 \%$ Triton X100 (Sigma-Aldrich) in PBS for $1 \mathrm{~h}$. Primary antibodies were diluted in a blocking solution at the followed dilutions; anti- $\beta$ III-tubulin $(1: 1,000$; Sigma-Aldrich), antiNESTIN (1:500; MERK), anti-LC3I/II (1:1,000; MERK), antiCD90-FITC (1:500; MERK), anti-Endoglin-CD105 (1:200; MERK) and anti-CD73 (1:500; MERK). Primary antibodies were applied overnight at $4^{\circ} \mathrm{C}$. Cells were then washed $3 \mathrm{X}$ with washing buffer (PBS, $0.1 \%$ Triton X100), followed by the incubation of secondary antibodies conjugated with either Alexa fluorophore 488 or 593 at 1:1,000 for $1 \mathrm{~h}$ at room temperature. Cells were washed 3 times in PBS and incubated with DAPI for nuclear staining (Biorad; Hercules, CA, USA).

Reverse transcription polymerase chain reaction (RT-PCR). Cells were detached by $0.25 \%$ trypsin-EDTA (Hyclone) and centrifuged at $11,000 \mathrm{rpm}$ for $5 \mathrm{~min}$. Total RNA was extracted by the RNA minikit (Nucleospin; Duran, Germany). $300 \mathrm{ng}$ of total RNA sample were used for each reverse transcription with the cDNA kit (Toyobo; Osaka, Japan). Primers of PCR were obtained from Macrogen (Seoul, Republic of Korea) and are listed in Table I. GAPDH was used as an internal control gene to normalize gene expression in each sample. cDNA was amplified by a thermal cycler PCR machine (Bio-Rad).

Statistical analysis. Results from different experiments were analyzed using GraphPad Prism v5.0 (GraphPad Software, San Diego, CA, USA). All data are expressed as means \pm standard deviation (SD). Statistical analysis of the data was performed using one-way ANOVA, followed by the Turkey post-hoc test. A $p$-Value $<0.05$ denoted the presence of a statistically significant result, whereas $p<0.01$ was considered highly significant.

\section{Results}

Derivation and Characterization of hPMSCs from human placental tissues. We isolated hPMSCs from human placental tissues of by the serial digestion of collagenase/dispase enzyme. hPMSCs adhered onto a culture dish after a 24-h isolation and cell migration was detected after 3 days. Interestingly, hPMSCs showed a fibroblast-like structure, and reached $100 \%$ confluency at day 14 post-isolation. hPMSCs were then harvested by $0.25 \%$ trypsin and expanded to passage 1 (Figure 1A). The expression of several cell surface protein markers, typical of hPMSCs and MSCs and indicative of the differentiation state, was analyzed using immunofluorescence and flow cytometry. Immunostaining results showed that hPMSCs strongly expressed CD73, CD90 and CD105 (Figure 1B). Identification of MSC characteristics by flow cytometry emphasized the homogeneity of hPMSCs, regarding MSC cell surface markers. The major population of hPMSCs were positively marked by CD73, CD90 and CD105, but not by hematopoietic stem cells markers CD34 and CD45 (Figure 1C). Finally, confirming their mesenchymal characteristics, we found that hPMSCs had an osteogenic, chondrogenic and adipogenic potential. The multipotent differentiation of hPMSCs was then examined by inducing mesodermal differentiation into osteogenic, chondrogenic, and adipogenic lineages. After 21 days of induction, hPMSCs possessed the typical mesenchymal stem cell differentiation propensity and became osteocytes, chondrocytes and adipocytes. The resulting adipocytes exhibited lipid droplet-containing cells as stained by Oil Red O, while chondrocytes and osteocytes were detected by Alcian Blue and Alizarin Red, respectively (Figure 1D).

Inhibition of notch signaling induced neural differentiation and upregulated autophagy genes in hPMSCs. The involvement of Notch signaling in neural differentiation has previously been investigated $(25,26)$. We aimed to explore the effect of inhibiting Notch signaling and whether it can influence neural differentiation of hPMSCs. DAPT, a $\gamma$ - 

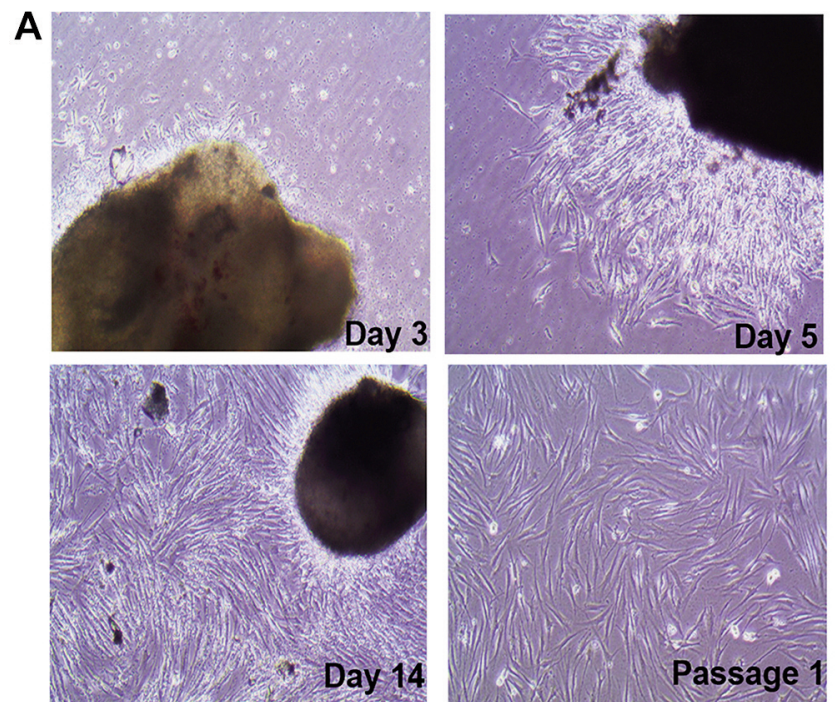
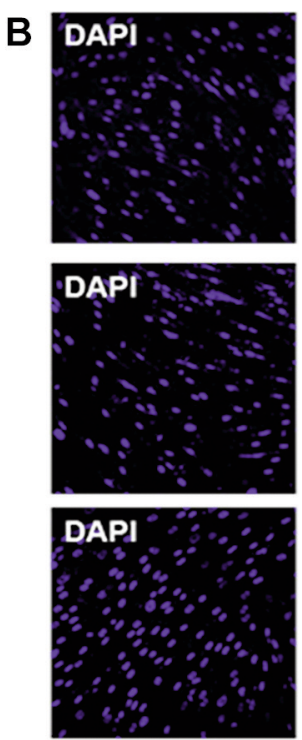
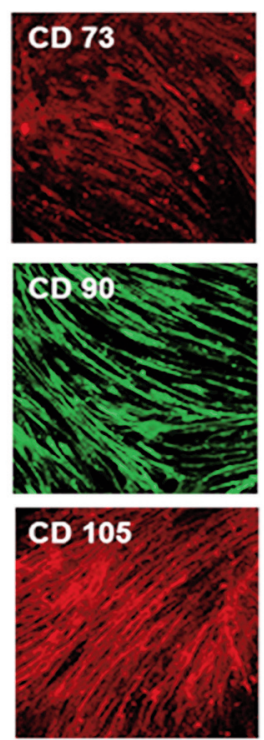
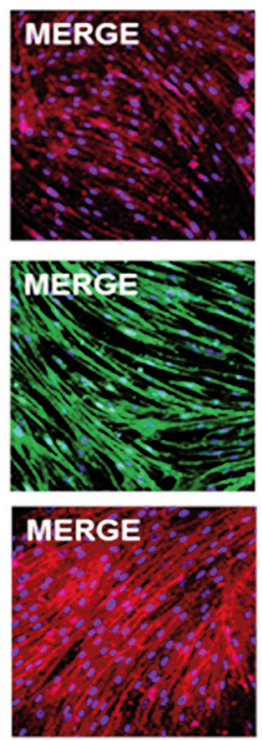

C

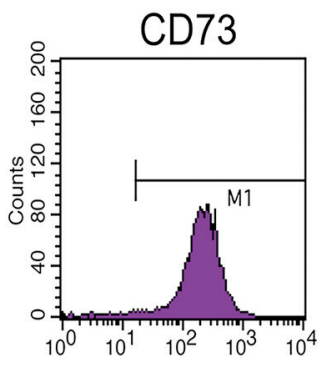

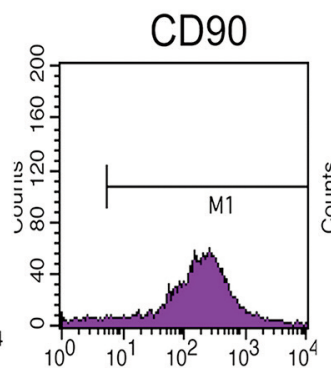
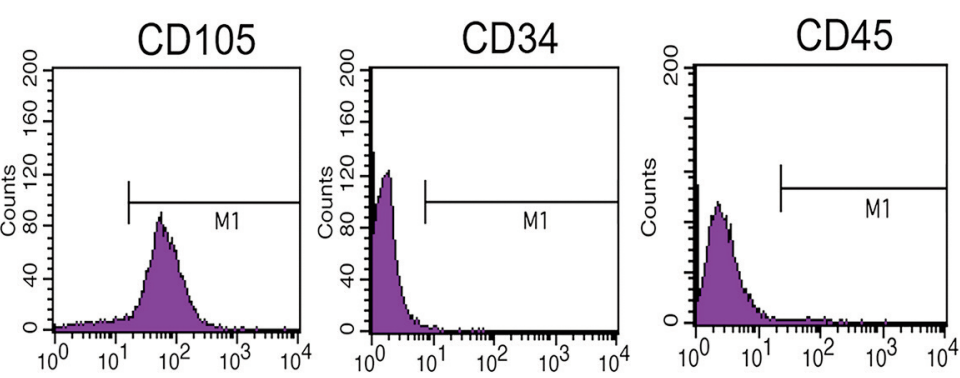

D
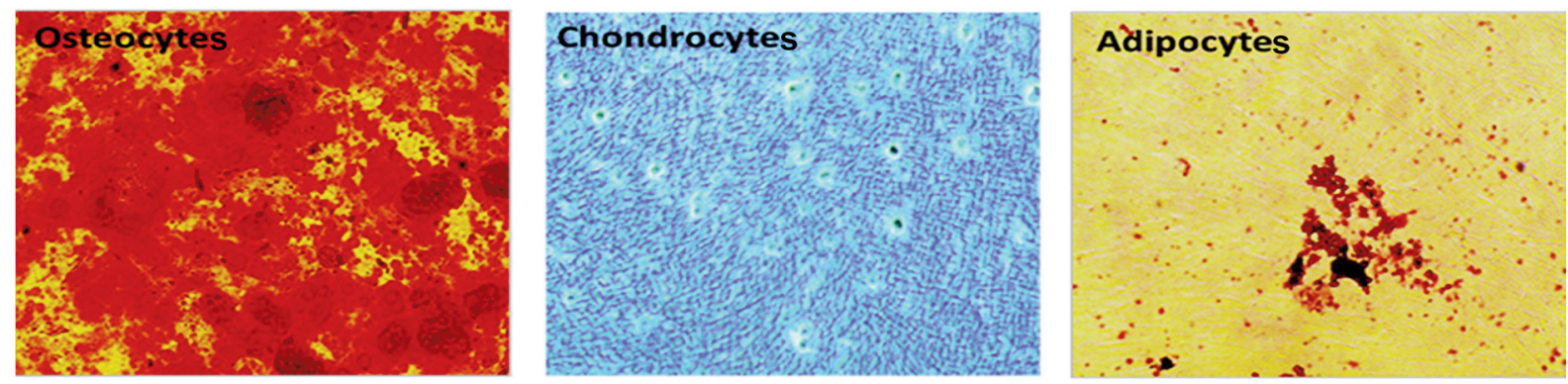

Figure 1. Isolation and characterization of human placenta-derived stem cells. (A) Bright field images of cellular morphology of primary culture expanded from placental tissues. Fibroblast-like cells of hPMSCs emigrated from digested placental tissues and adhered to the culture dish at day 3, 5 and 14 post-isolation, and hPMSCs at passage 1.(B) Immunocytochemistry of hPMSCs for mesenchymal stem cell surface antigens including CD73, CD90 and CD105. (C) A major population of hPMSCs was positive for CD73, CD90 and CD105, and negative for CD34 and CD45, as analyzed by flow cytometry. (D) Multipotent differentiation of hPMSCs for osteocytes, chondrocytes, and adipocytes was demonstrated by lipid droplets with Oil-Red $O$, mineral nodules with Alizarin red and proteoglycan matrix of Alcian blue.

secretase inhibitor, was used for inhibiting Notch signaling and induce neural differentiation of hPMSCs. Various concentrations of DAPT $(0,5,10$ and $20 \mu \mathrm{M})$ were supplied into the differentiation culture for 7 days prior to assessing the expression of neural genes. At day 7, the structure of hPMSCs in 5, 10, $20 \mu \mathrm{M}$ DAPT presented a spindle-shaped morphology (Figure 2A). Neuronal genes, including Nestin, $\beta I I I$-tubulin, and SOX2, were significantly upregulated when
10 and $20 \mu \mathrm{M}$ of DAPT was applied (Figure 2B, C). Interestingly, the autophagy genes LC3I/II and Beclin were also significantly upregulated when Notch signaling was blocked by 10 and $20 \mu \mathrm{M}$ DAPT, compared to the undifferentiated control cells (Figure 2D, E), suggesting that autophagy plays a role in the differentiationprocess. These data exhibited that DAPT promoted neural differentiation and enhanced the activity of autophagy in hPMSCs. 

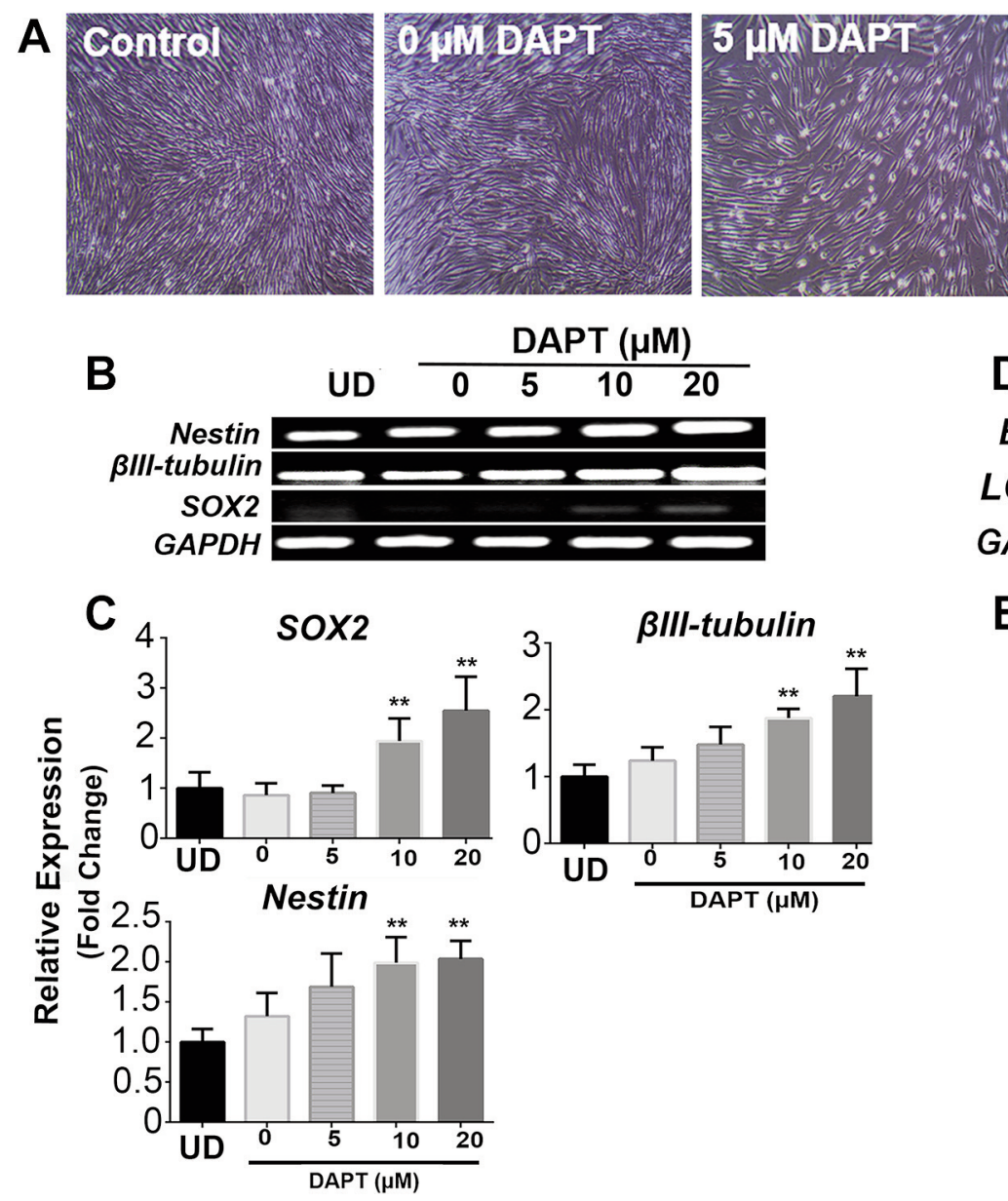
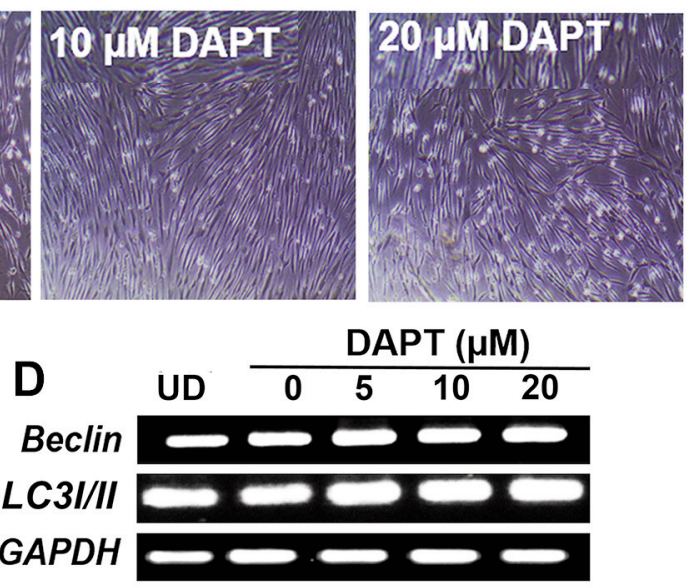

E

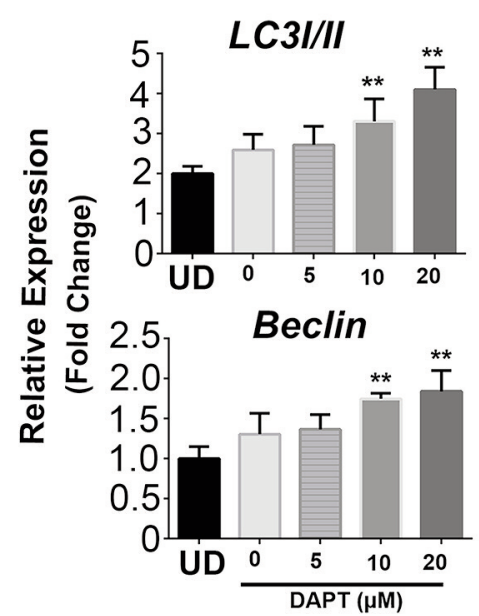

Figure 2. Inhibition of Notch signaling promoted neural differentiation of hPMSCs. (A) hPMSCs were cultured under various concentrations of $D A P T(0,5,10,20 \mu \mathrm{M})$ for 7 days, and their morphology was observed under the light microscope. (B) The expression of neural genes, Nestin, BII-tubulin, and SOX2, was determined by RT-PCR. (C) The expression levels were normalized to GAPDH, and the relative expression was calculated over the undifferentiated control cells. (D) Autophagy genes, LC3I/II and Beclin, were upregulated when hPMSCs were induced to differentiate by $D A P T$. (E) Quantification of autophagic genes was performed by using GAPDH as a reference gene. Values are expressed as mean $\pm S D(n=3)$. $* * p<0.01$ vs. undifferentiated control cells.

5-Azacytidine enhanced neural differentiation efficiency and activated autophagy of hPMSCs. More recent studies have examined how autophagy could enhance neural differentiation; recent evidence show autophagy is involved in the efficiency of stem cell differentiation. In addition to DNA demethylating agents, a number of studies have found 5 -Azacytidine can induce autophagy in various contexts (27, 28). In this regard, the ability of 5-Azacytidine in enhancing neural differentiation was evaluated. hPMSCs were differentiated into neural-like cells in the differentiation media with either $10 \mu \mathrm{M}$ DAPT or $10 \mu \mathrm{M}$ 5-Azacytidine alone or in combination. After 7 days of differentiation, the morphology of hPMSCs became neural in all differentiation conditions, compared with the undifferentiated control cells (Figure 3A). The combined treatment of DAPT and 5-
Azacytidine resulted in the highest expression of neural genes, Nestin and BIII-tubulin, as well as GADI, a marker of glutaminergic neurons as measured by RT-PCR (Figure 3B, C). Immunofluorescence confirmed that the combined treatment of DAPT and 5-Azacytidine induced the neural markers Nestin and $\beta$ III-tubulin in differentiated hPMSCs (Figure 3D). This result indicates that 5-Azacytidine could enhance the efficiency of neural differentiation of hPMSCs. Furthermore, the influence of 5-Azacytidine in autophagy was investigated. The expression of LC3I/II and BECLIN was determined after 7 days of neural differentiation in various conditions; either $10 \mu \mathrm{M}$ DAPT or $10 \mu \mathrm{M} 5$ Azacytidine alone or in combination. The combined treatment of DAPT and 5- Azacytidine significantly augmented the expression of LC3I/II and BECLIN genes, 

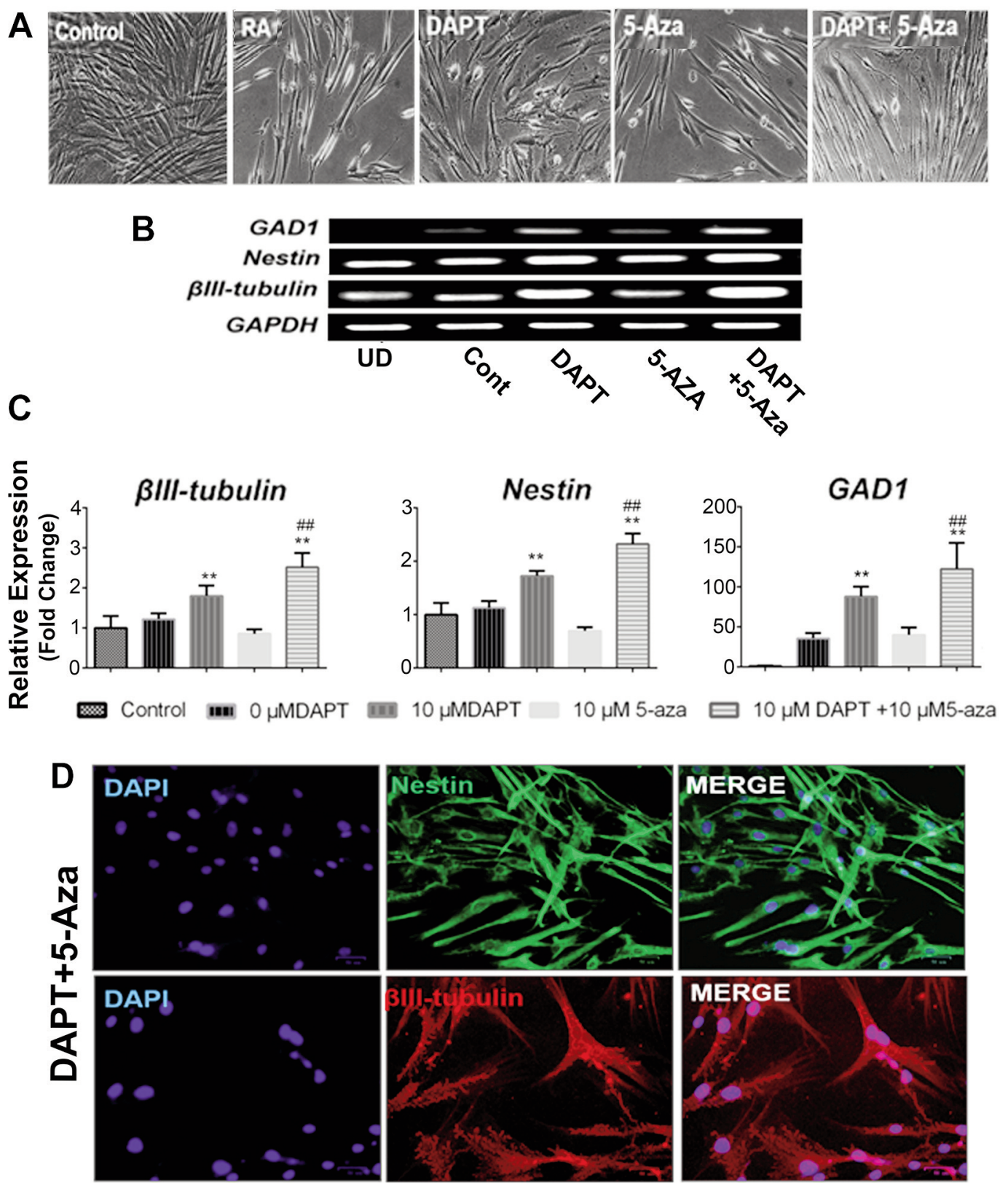

Figure 3. 5-Azacytidine enhanced neural differentiation of hPMSCs. (A) Morphology of differentiated hPMSCs in various conditions at day 7. (B) The expression of neural genes, GAD1, Nestin, and BIII-tubulin, was assessed by RT-PCR. (C) The relative expression levels of neural genes were quantified by normalization with GAPDH. Values are expressed as mean $\pm S D(n=3) . * * p<0.01$ vs. undifferentiated control cells, and ${ }^{\# \#} p<0.01$ vs. DAPT-treated cells. (D) Immunofluorescent images of Nestin and BII-tubulin of differentiated hPMSCs with $10 \mu M$ DAPT and $10 \mu M$ 5-Azacytidine at day 7.

compared to the undifferentiated control and DAPT treatment alone (Figure 4A, B). LC3I/II and BECLIN were also found to co-localize with $\beta$ III-tubulin in hPMSCsderived neural cells, validating the activation of autophagy (Figure 4C). This data suggested that supplying 5Azacytidine in inductive medium could promote autophagic activity resulting in enhanced neural differentiation.
Modulation of autophagy influenced the efficacy of neural differentiation of hPMSCs. We next confirmed the influence of autophagy during neural differentiation of hPMSCs. To address this, we applied small molecules are known to modulate autophagy. Chloroquine (CQ) or Valproic acid (VPA) were used to either block or enhance autophagy within cells. The changes of cellular morphology were 
A

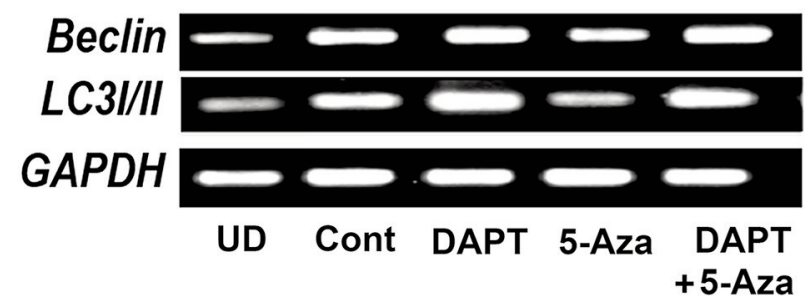

B

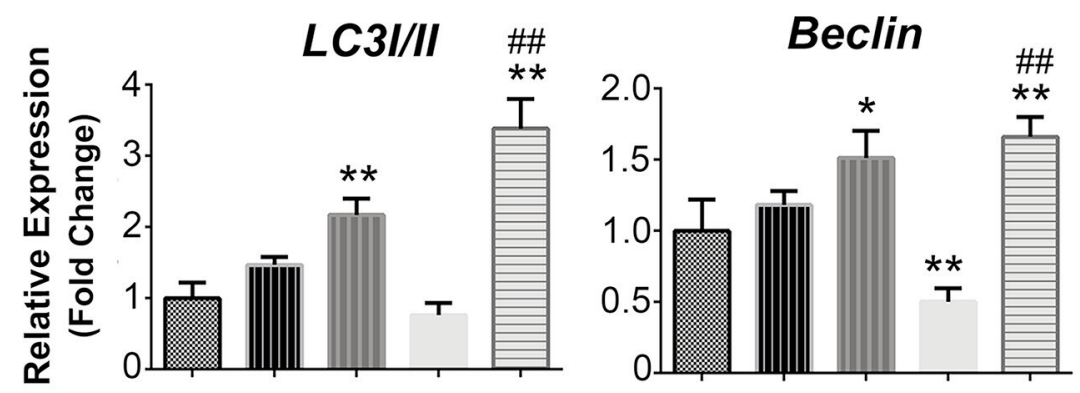

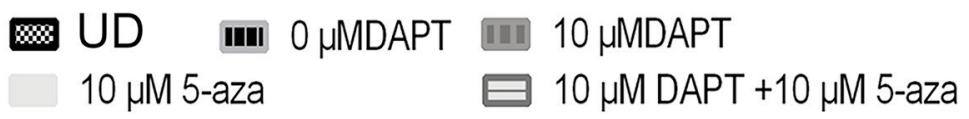
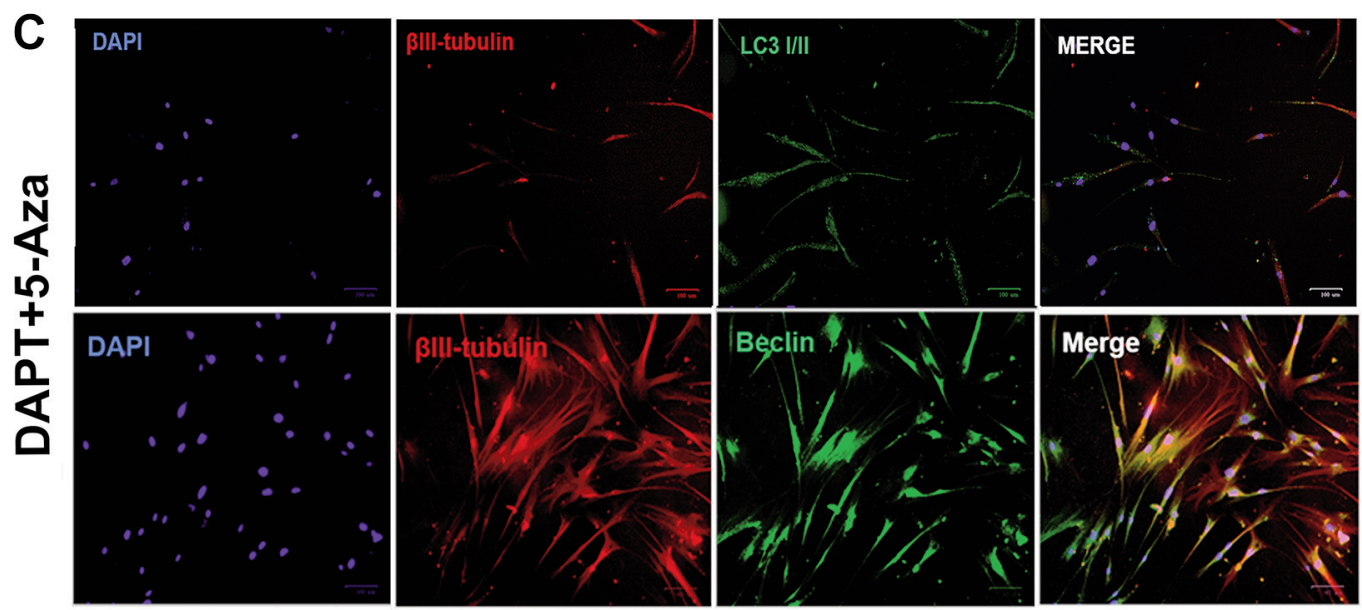

Figure 4. Autophagy was activated during neural differentiation of hPMSCs. (A) The expression of LC3I/II and BECLIN was determined by RT$P C R$. (B) The relative expression levels were measured by normalization with GAPDH. Values are expressed as mean $\pm S D(n=3) . * p<0.05$ and ${ }^{* *} p<0.01$ vs. the undifferentiated control cells and ${ }^{\# \#} p<0.01$ versus DAPT-treated cells. Immunofluorescent images (C) of $\beta I I I-t u b u l i n($ red $)$ and LC3I/II (green) are merged with DAPI (blue), as well as BIII-tubulin (red) and LC3I/II (green).

observed at day 1, 5 and 7 of differentiation. Compared to the differentiation control, VPA further induced spindle-like cells, while CQ caused prominent cell death (Figure 5A). The expression of $\beta I I I-t u b u l i n$ and $L C 3 I / I I$ was assessed at day 1,5 , and 7 of differentiation by RT-PCR (Figure 5B). Compared to control, VPA significantly enhanced $L C 3 I / I I$ expression at day 7, while CQ did not have a notable change (Figure 5C). BIII-tubulin was also significantly increased in
VPA-induced hPMSCs and its level was clearly suppressed in CQ-supplemented conditions (Figure 5C). Consistently, immunofluorescence results showed that the treatment of chloroquine led to the reduction of $\beta$ III-tubulin-positive cells, in contrast to VPA-treated hPMSCs (Figure 5D). These results propose that neural differentiation of hPMSCs can be modulated by autophagy within cells; the more autophagic activity, the higher the neural differentiation efficiency. 
A D3

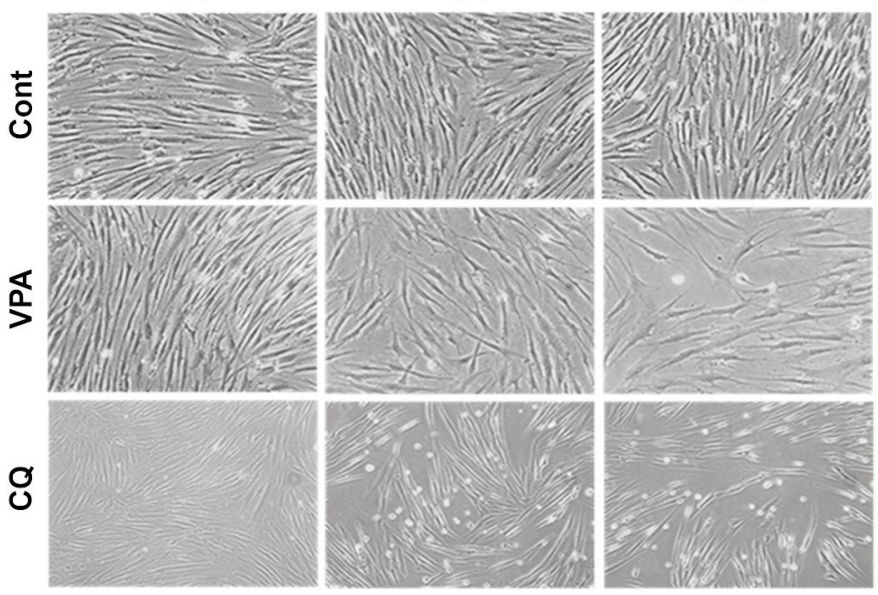

B

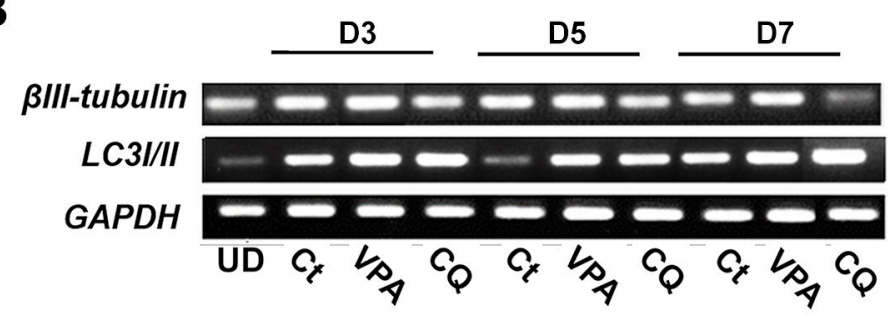

C

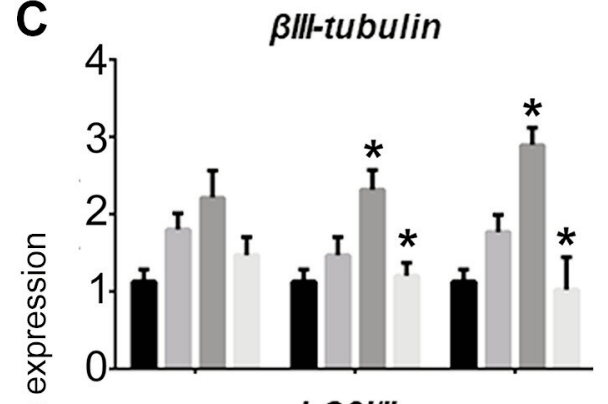

$\frac{1}{\frac{N}{0}}$

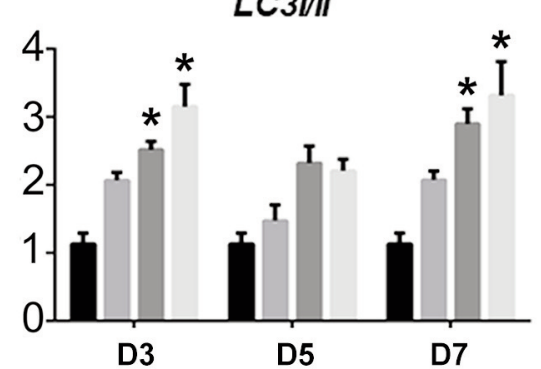

Control

DAPT + 5-aza

DAPT + 5-aza+ VPA

$\mathrm{DAPT}+5-\mathrm{aza}+\mathrm{Cq}$

D

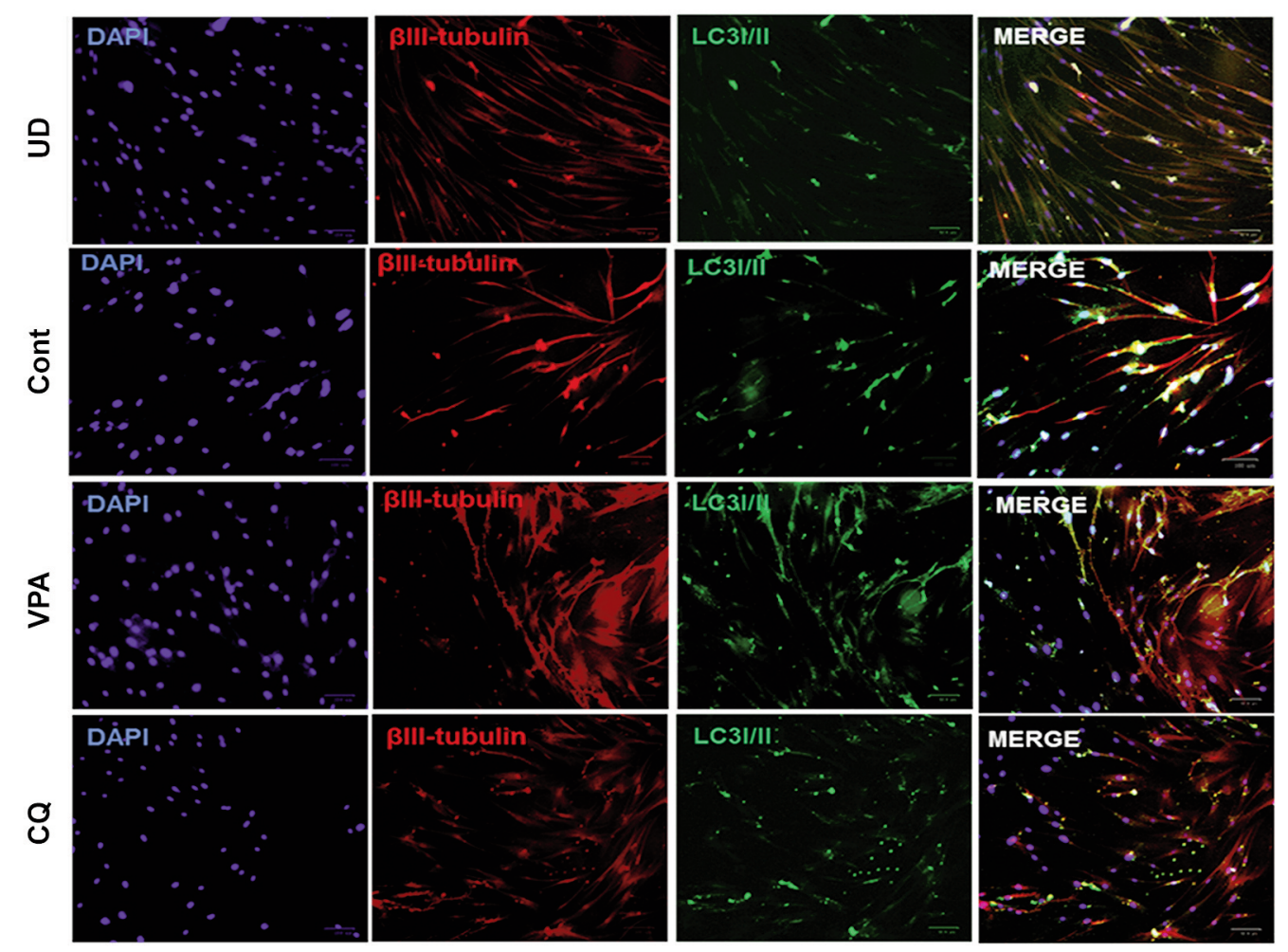

Figure 5. The modulation of autophagy altered neural differentiation of hPMSCs. (A) Morphological changes of hPMSCs during neural differentiation, when either an autophagy activator (Valproic acid; VPA) or an autophagy inhibitor (chloroquine; CQ) was supplemented. (B) The expression of BIII-tubulin and LC3I/II was determined by RT-PCR. (C) VPA significantly enhanced the expression of LC3I/II and $\beta I I I-t u b u l i n$, compared with the differentiated control cells. Data are shown as mean $\pm S D .{ }^{*} p<0.05 v$ s. the differentiated control cells. (D) The immunofluorescent images showed colocalization of BIII-tubulin and LC3I/II when VPA was added to the cells. 


\section{Differentiation of hPMSCs}

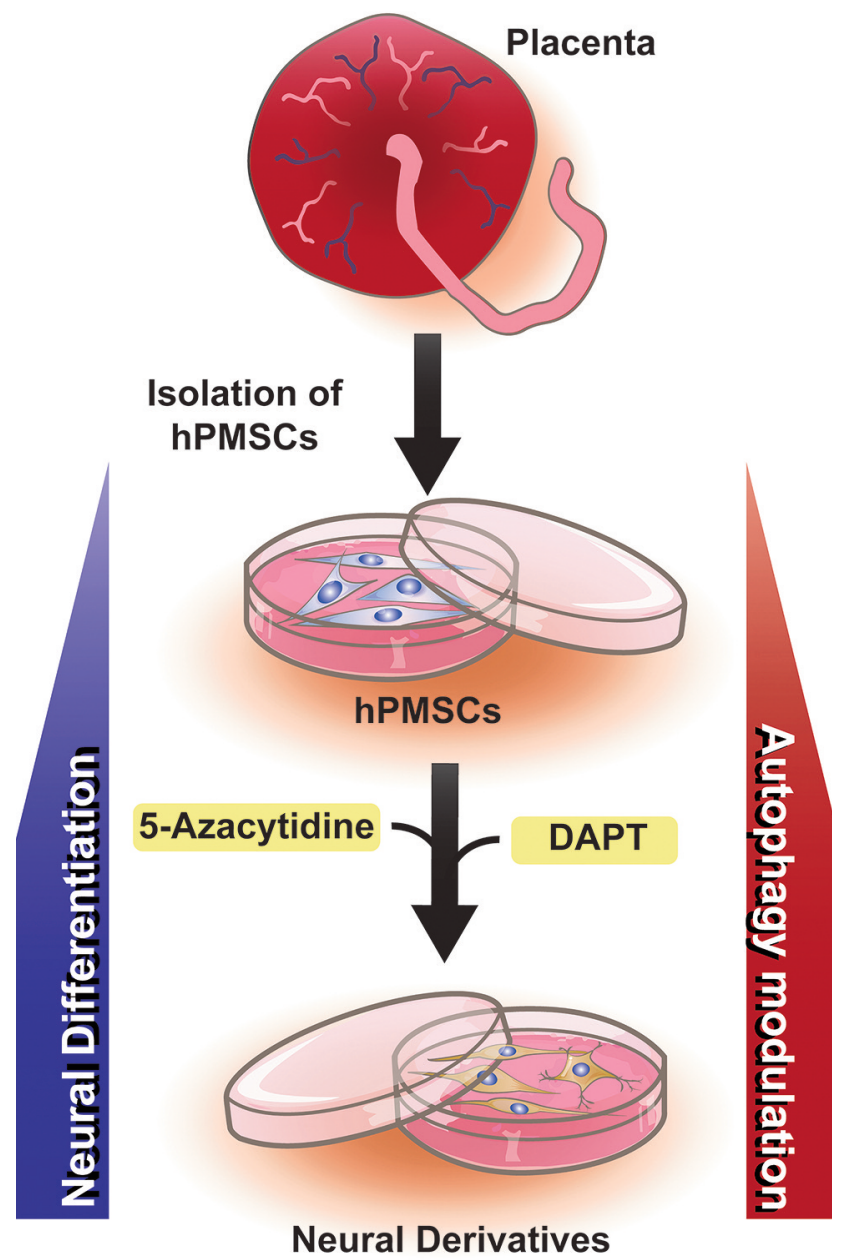

Figure 6. Graphical image depicting the involvement of autophagy during neural differentiation of hPMSCs. Autophagy was induced during neural differentiation of hPMSCs; therefore, the optimized autophagic activity could refine the efficiency of neural differentiation from hPMSCs.

\section{Discussion}

In this study, we demonstrated that hPMSCs isolated from the placental tissues exhibited fibroblastic appearance in primary culture and maintained stemness by expression of MSCs markers (CD73, 90, 105), but not hematopoietic stem cell (HSC) markers (CD34, 45). However, it has been suggested that when the isolated hPMSCs are MSC-like, they present immunoprivileged properties which would not cause an inflammatory response (29). Our first goal was to determine whether the isolated hPMSCs maintained their multiple lineage differentiation ability. Similar to others, we found that hPMSCs in this study possessed the differentiation capacity into adipocytes, osteocytes, and chondrocytes (30-32).

This study set out with the aim of assessing the differentiation efficiency, and we were able to induce hPMSCs towards neurons by inhibiting Notch signaling and DNA methylation. Notch signaling plays a critical role in development and cell fate specification. Notch receptors and ligands have been found to be expressed and play fundamental roles during the developmental process of the placenta (33). Prior studies have suggested that inhibition of Notch signaling is associated with neuronal differentiation $(26,34)$. Notch signaling can be suppressed by a $\gamma$-secretase inhibitor, DAPT (35). Thus, we used DAPT in varying concentrations together with N2 medium and retinoic acid, which have the ability to induce post-mitotic, neural phenotypes in various types of stem cells $(36,37)$. Upon induction, we could detect increasing expression of $\beta I I I-$ tubulin Nestin, and SOX2 in cells treated with DAPT during the neural differentiation protocol. Only cells treated with 10 and $20 \mu \mathrm{M}$ were found to clearly express $S O X 2$, therefore, we chose DAPT at a concentration of $10 \mu \mathrm{M}$ for Notch inhibition and further experiments. We observed increased expression of autophagy genes (LC3I/II, BECLIN) upon treatment with DAPT in a dose-dependent manner. Hence, it could be hypothesized that autophagy plays a role in neuronal differentiation once Notch singling is inhibited.

We further examined the potential of DAPT and 5Azacytidine in enhancing neuronal differentiation. Notably, the neural marker genes were utmost upregulated when combining DAPT and 5-Azacytidine. High expression of both Nestin and RIII-tubulin in hPMSCs was observed. This indicated that hPMSCs can efficiently differentiate into neural-like cells with DAPT treatment, and 5-Azacytidine could further enhance neuronal differentiation. hPMSCs are able to differentiate into neural precursors, but limited evidence was found in prior studies on hPMSCs differentiation into mature neurons $(38,39)$. Intriguingly, we further found $G A D 1$, a marker of glutaminergic neurons, was highly expressed when hPMSCs were simultaneously treated with DAPT and 5-Azacytidine. The neural markers we characterized included both Nestin and BIII-tubulin. Nestin is known to be expressed within mesenchymal stem cells, and the expression of Nestin was increased when cells differentiated into neurons (40). $\beta I I I$-tubulin is expressed after neuronal differentiation and utilized as a marker of mature neurons during the final stages of growth $(41,42)$. Our results were similar to a previous study that reported Notch inhibition by DAPT and subsequent differentiation of human induced pluripotent stem cells towards a neural fate (43).

In addition, the epigenetic modifier 5-Azacytidine was used to enhance the neural differentiation potential in this study. In 2013, Zemelko and colleagues reported that retinoic acid (RA) in combination with 5-azacytidine caused the 
elevation neurogenic potential of adipose-derived MSCs (44). Another study reported that adipose-derived mesenchymal stem cells (ASCs) maintained in the medium with RA and 5-Azacytidine for 7 days had increased mRNA and protein levels of Nestin and BIII-tubulin (45). Similar to our study, the combination 5-Azacytidine with DAPT medium promoted a neural-like cell production from hPMSCs-MSCs at a greater rate than DAPT alone. Thus, it could be suggested that only two small molecules, 5Azacytidine cytidine and DAPT, can potentially direct hPMSC reprograming toward neuronal cells. In addition to the inhibition of Notch signaling, expression of autophagy genes (LC3I/II, BECLIN) was enhanced upon DAPT treatment, in a dose-dependent manner. Most recent data show that bone marrow mononucleated cells exposed to 5Azacytidine express increased proteins associated with autophagy (46). Hence, it could be hypothesized that autophagy plays a role in neuronal differentiation, once Notch singling is inhibited. In line with the previous observation, the expression of LC3I/II, an autophagy marker, peaked after the induction and demonstrated the same trend as neural differentiation (47). Moreover, autophagic activity was upregulated during the neuronal differentiation of Neuro 2A (N2a) cells (48). In previous studies, autophagy was shown to play an important role in support and protection of cells during differentiation (49-53). This evidence implies that autophagic activity may be an important supportive condition in neural cell differentiation, and it is activated in response to the neural differentiation signals (Figure 6).

Therefore, it is promising that there are connections between autophagy and the neural differentiation of hPMSCs. We validated the role of autophagy in this regard by using chemical modulators; an autophagy activator and an autophagy inhibitor. Valproic acid (VPA), a histone deacetylase inhibitor (HDAC), has been widely used for activating autophagy, which could then induce cell differentiation (54). Chloroquine is an anti-malarial drug, and it is generally accepted as an autophagy inhibitor that leads to a massive accumulation of ubiquitinated LC3I/II (55). Besides autophagy activation, the treatment of VPA promotes neural markers, contrasting with the addition of chloroquine and the control. These data propose that neural differentiation of hPMSCs occurs in conjunction with the activation of autophagy $(56,57)$. However, there are more complex signaling factors involved in the regulation of neuronal differentiation and the mechanistic relationship between Notch signaling and autophagy requires further exploration.

\section{Conclusion}

The combination of DAPT and 5-Azacytidine efficiently induced neural differentiation of hPMSCs and autophagy was significantly activated upon stem cell differentiation.
The levels of autophagic activity positively correlated with the efficiency of neural differentiation, suggesting that autophagy might play a role in regulating stem cell differentiation (Figure 6).

\section{Conflicts of Interest}

The Authors declare no conflicts of interest regarding this study.

\section{Authors' Contributions}

Areechun Sotthibundhu provided concept and design of the study, performed experiments, analyzed and interpreted data and prepared the article for publication. Pattamon Muangchan performed experiments, analyzed and interpreted data. Ruchee Phonchai performed experiments, provided resources, prepared the article for publication. Wilasinee Promjantuek collected samples, analyzed and interpreted data. Nipha Chaicharoenaudomrung analyzed and interpreted data and prepared the article for publication. Phongsakorn Kunhorm analyzed and interpreted data and prepared the article for publication.Parinya Noisa provided the concept and design of the study, collected samples, analyzed and interpreted data, wrote the manuscript, prepared the article for publication and gave the final publication approval of the manuscript.

\section{Acknowledgements}

This work was supported by the National Research Council of Thailand (NRCT), Suranaree University of Technology (SUT) and by Thailand Science Research and Innovation (TSRI), and Research Fund for DPST Graduate with First Placement (Grant no.035/2558).

\section{References}

1 Vishnubhatla I, Corteling R, Stevanato L, Hicks C and Sinden $\mathrm{J}$ : The development of stem cell-derived exosomes as a cell-free regenerative medicine. Journal of Circulating Biomarkers 3: 2, 2020. DOI: $10.5772 / 58597$

2 Watt FM and Driskell RR: The therapeutic potential of stem cells. Philos Trans R Soc Lond B Biol Sci 365(1537): 155-163, 2010. PMID: 20008393. DOI: 10.1098/rstb.2009.0149

3 Nombela-Arrieta C, Ritz J and Silberstein LE: The elusive nature and function of mesenchymal stem cells. Nat Rev Mol Cell Biol 12(2): 126-131, 2011. PMID: 21253000. DOI: 10.1038/nrm3049

4 Oliveira MS and Barreto-Filho JB: Placental-derived stem cells: Culture, differentiation and challenges. World J Stem Cells 7(4): 769-775, 2015. PMID: 26029347. DOI: 10.4252/wjsc.v7.i4.769

5 Sabapathy V, Ravi S, Srivastava V, Srivastava A and Kumar S: Long-term cultured human term placenta-derived mesenchymal stem cells of maternal origin displays plasticity. Stem Cells Int 2012: 174328, 2012. PMID: 22550499. DOI: 10.1155/ 2012/174328

6 Pop DM, SoriŢău O, Şuşman S, Rus-Ciucă D, Groza IŞ, Ciortea R, Mihu D and Mihu CM: Potential of placental-derived human mesenchymal stem cells for osteogenesis and neurogenesis. Rom J Morphol Embryol 56(3): 989-996, 2015. PMID: 26662130. 
7 Juan $\mathrm{CH}$, Chen $\mathrm{MH}$, Lin $\mathrm{FH}$, Wong $\mathrm{CS}$, Chien $\mathrm{CC}$ and Chen $\mathrm{MH}$ : In vitro differentiation of human placenta-derived multipotent cells into Schwann-like cells. Biomolecules 10(12): 1657, 2020. PMID: 33322066. DOI: 10.3390/biom10121657

8 Yen BL, Chien CC, Chen YC, Chen JT, Huang JS, Lee FK and Huang HI: Placenta-derived multipotent cells differentiate into neuronal and glial cells in vitro. Tissue Eng Part A 14(1): 9-17, 2008. PMID: 18333820. DOI: 10.1089/ten.a.2006.0352

9 Ramasamy SK and Lenka N: Notch exhibits ligand bias and maneuvers stage-specific steering of neural differentiation in embryonic stem cells. Mol Cell Biol 30(8): 1946-1957, 2010. PMID: 20154142. DOI: 10.1128/MCB.01419-09

10 Jönsson JI, Xiang Z, Pettersson M, Lardelli M and Nilsson G: Distinct and regulated expression of Notch receptors in hematopoietic lineages and during myeloid differentiation. Eur J Immunol 31(11): 3240-3247, 2001. PMID: 11745340. DOI: 10.1002/1521-4141(200111)31:11<3240::aid-immu3240>3.0.co;2-e

11 Gude N, Joyo E, Toko H, Quijada P, Villanueva M, Hariharan N, Sacchi V, Truffa S, Joyo A, Voelkers M, Alvarez R and Sussman MA: Notch activation enhances lineage commitment and protective signaling in cardiac progenitor cells. Basic Res Cardiol 110(3): 29, 2015. PMID: 25893875. DOI: 10.1007/ s00395-015-0488-3

12 Løvschall H, Tummers M, Thesleff I, Füchtbauer EM and Poulsen K: Activation of the Notch signaling pathway in response to pulp capping of rat molars. Eur J Oral Sci 113(4): 312-317, 2005. PMID: 16048523. DOI: 10.1111/j.1600-0722.2005.00221.x

13 Engin F and Lee B: NOTCHing the bone: insights into multifunctionality. Bone 46(2): 274-280, 2010. PMID: 19520195. DOI: $10.1016 /$ j.bone.2009.05.027

14 Wang J, Ye Z, Zheng S, Chen L, Wan Y, Deng Y and Yang R: Lingo-1 shRNA and Notch signaling inhibitor DAPT promote differentiation of neural stem/progenitor cells into neurons. Brain Res 1634: 34-44, 2016. PMID: 26607252. DOI: 10.1016/ j.brainres.2015.11.029

15 Kageyama R, Ohtsuka T, Shimojo H and Imayoshi I: Dynamic Notch signaling in neural progenitor cells and a revised view of lateral inhibition. Nat Neurosci 11(11): 1247-1251, 2008. PMID: 18956012. DOI: $10.1038 / \mathrm{nn} .2208$

16 Kanungo J, Zheng YL, Amin ND and Pant HC: The Notch signaling inhibitor DAPT down-regulates cdk5 activity and modulates the distribution of neuronal cytoskeletal proteins. J Neurochem 106(5): 2236-2248, 2008. PMID: 18662245. DOI: 10.1111/j.1471-4159.2008.05551.x

17 Sheaffer KL, Kim R, Aoki R, Elliott EN, Schug J, Burger L, Schübeler D and Kaestner KH: DNA methylation is required for the control of stem cell differentiation in the small intestine. Genes Dev 28(6): 652-664, 2014. PMID: 24637118. DOI: $10.1101 / \operatorname{gad} .230318 .113$

18 Holliday $\mathrm{R}$ and Ho T: DNA methylation and epigenetic inheritance. Methods 27(2): 179-183, 2021. DOI: 10.1016/ S1046-2023(02)00072-5

19 Gailhouste L, Liew LC, Hatada I, Nakagama H and Ochiya T: Epigenetic reprogramming using 5-azacytidine promotes an anticancer response in pancreatic adenocarcinoma cells. Cell Death Dis 9(5): 468, 2018. PMID: 29700299. DOI: 10.1038/s41419018-0487-z

20 Vessoni AT, Muotri AR and Okamoto OK: Autophagy in stem cell maintenance and differentiation. Stem Cells Dev 21(4): $513-$ 520, 2012. PMID: 22066548. DOI: 10.1089/scd.2011.0526
21 Mizushima N: Autophagy: process and function. Genes Dev 21(22): 2861-2873, 2007. PMID: 18006683. DOI: 10.1101/gad.1599207

22 Pantovic A, Krstic A, Janjetovic K, Kocic J, Harhaji-Trajkovic L, Bugarski D and Trajkovic V: Coordinated time-dependent modulation of AMPK/Akt/mTOR signaling and autophagy controls osteogenic differentiation of human mesenchymal stem cells. Bone 52(1): 524-531, 2013. PMID: 23111315. DOI: 10.1016/j.bone.2012.10.024

23 Zhang Z, Zhang L, Zhou Y, Li L, Zhao J, Qin W, Jin Z and Liu W: Increase in HDAC9 suppresses myoblast differentiation via epigenetic regulation of autophagy in hypoxia. Cell Death Dis 10(8): 552, 2019. PMID: 31320610. DOI: 10.1038/s41419-019-1763-2

24 Pelekanos RA, Sardesai VS, Futrega K, Lott WB, Kuhn M and Doran MR: Isolation and expansion of mesenchymal stem/stromal cells derived from human placenta tissue. J Vis Exp (112): 54204, 2016. PMID: 27340821. DOI: 10.3791/54204

25 Coste C, Neirinckx V, Gothot A, Wislet S and Rogister B: Are neural crest stem cells the missing link between hematopoietic and neurogenic niches? Front Cell Neurosci 9: 218, 2015. PMID: 26136659. DOI: 10.3389/fncel.2015.00218

26 Cardozo AJ, Gómez DE and Argibay PF: Transcriptional characterization of Wnt and Notch signaling pathways in neuronal differentiation of human adipose tissue-derived stem cells. J Mol Neurosci 44(3): 186-194, 2011. PMID: 21360053. DOI: $10.1007 / \mathrm{s} 12031-011-9503-9$

27 Hsieh YY, Huang TC, Lo HL, Jhan JY, Chen ST and Yang PM: Systematic discovery of drug action mechanisms by an integrated chemical genomics approach: identification of functional disparities between azacytidine and decitabine. Oncotarget 7(19): 2736327378, 2016. PMID: 27036028. DOI: 10.18632/oncotarget.8455

28 Cluzeau T, Robert G, Puissant A, Jean-Michel K, Cassuto JP, Raynaud S and Auberger P: Azacitidine-resistant SKM1 myeloid cells are defective for AZA-induced mitochondrial apoptosis and autophagy. Cell Cycle 10(14): 2339-2343, 2011. PMID: 21654192. DOI: $10.4161 / \mathrm{cc} .10 .14 .16308$

29 Rastegar F, Shenaq D, Huang J, Zhang W, Zhang BQ, He BC, Chen L, Zuo GW, Luo Q, Shi Q, Wagner ER, Huang E, Gao Y, Gao JL, Kim SH, Zhou JZ, Bi Y, Su Y, Zhu G, Luo J, Luo X, Qin J, Reid RR, Luu HH, Haydon RC, Deng ZL and He TC: Mesenchymal stem cells: Molecular characteristics and clinical applications. World J Stem Cells 2(4): 67-80, 2010. PMID: 21607123. DOI: $10.4252 /$ wjsc.v2.i4.67

30 Beeravolu N, McKee C, Alamri A, Mikhael S, Brown C, PerezCruet $\mathrm{M}$ and Chaudhry GR: Isolation and characterization of mesenchymal stromal cells from human umbilical cord and fetal placenta. J Vis Exp (122): 55224, 2017. PMID: 28447991. DOI: $10.3791 / 55224$

31 Watson N, Divers R, Kedar R, Mehindru A, Mehindru A, Borlongan MC and Borlongan CV: Discarded Wharton jelly of the human umbilical cord: a viable source for mesenchymal stromal cells. Cytotherapy 17(1): 18-24, 2015. PMID: 25442786. DOI: $10.1016 /$ j.jcyt.2014.08.009

32 Bharti D, Shivakumar SB, Park JK, Ullah I, Subbarao RB, Park JS, Lee SL, Park BW and Rho GJ: Comparative analysis of human Wharton's jelly mesenchymal stem cells derived from different parts of the same umbilical cord. Cell Tissue Res 372(1): 51-65, 2018. PMID: 29204746. DOI: 10.1007/s00441-017-2699-4

33 Haider S, Pollheimer J and Knöfler M: Notch signalling in placental development and gestational diseases. Placenta 56: 6572, 2017. PMID: 28117145. DOI: 10.1016/j.placenta.2017.01.117 
34 Noisa P, Lund C, Kanduri K, Lund R, Lähdesmäki H, Lahesmaa $\mathrm{R}$, Lundin $\mathrm{K}$, Chokechuwattanalert $\mathrm{H}$, Otonkoski T, Tuuri $\mathrm{T}$ and Raivio T: Notch signaling regulates the differentiation of neural crest from human pluripotent stem cells. J Cell Sci 127(Pt 9): 2083-2094, 2014. PMID: 24569875. DOI: 10.1242/jcs.145755

35 Ogura A, Morizane A, Nakajima Y, Miyamoto S and Takahashi $\mathrm{J}$ : $\gamma$-secretase inhibitors prevent overgrowth of transplanted neural progenitors derived from human-induced pluripotent stem cells. Stem Cells Dev 22(3): 374-382, 2013. PMID: 23020188. DOI: $10.1089 / \mathrm{scd} .2012 .0198$

36 Janesick A, Wu SC and Blumberg B: Retinoic acid signaling and neuronal differentiation. Cell Mol Life Sci 72(8): 1559-1576, 2015. PMID: 25558812. DOI: 10.1007/s00018-014-1815-9

37 Kim BJ, Seo JH, Bubien JK and Oh YS: Differentiation of adult bone marrow stem cells into neuroprogenitor cells in vitro. Neuroreport 13(9): 1185-1188, 2002. PMID: 12151766. DOI: 10.1097/00001756-200207020-00023

38 Miao Z, Sun H and Xue Y: Isolation and characterization of human chorionic membranes mesenchymal stem cells and their neural differentiation. Tissue Eng Regen Med 14(2): 143-151, 2017. PMID: 30603471. DOI: 10.1007/s13770-017-0025-6

39 Zhang D, Tong A, Zhou L, Fang F and Guo G: Osteogenic differentiation of human placenta-derived mesenchymal stem cells (PMSCs) on electrospun nanofiber meshes. Cytotechnology 64(6): 701-710, 2012. PMID: 22526490. DOI: 10.1007/s10616$012-9450-5$

40 Martini MM, Jeremias Tda S, Kohler MC, Marostica LL, Trentin AG and Alvarez-Silva M: Human placenta-derived mesenchymal stem cells acquire neural phenotype under the appropriate niche conditions. DNA Cell Biol 32(2): 58-65, 2013. PMID: 23323927. DOI: $10.1089 /$ dna.2012.1807

41 Johansson CB, Momma S, Clarke DL, Risling M, Lendahl U and Frisén J: Identification of a neural stem cell in the adult mammalian central nervous system. Cell 96(1): 25-34, 1999. PMID: 9989494. DOI: 10.1016/s0092-8674(00)80956-3

42 Karaöz E, Doğan BN, Aksoy A, Gacar G, Akyüz S, Ayhan S, Genç ZS, Yürüker S, Duruksu G, Demircan PC and Sariboyaci AE: Isolation and in vitro characterisation of dental pulp stem cells from natal teeth. Histochem Cell Biol 133(1): 95-112, 2010. PMID: 19816704. DOI: 10.1007/s00418-009-0646-5

43 Chen CY, Liao W, Lou YL, Li Q, Hu B, Wang Y and Deng ZF: Inhibition of Notch signaling facilitates the differentiation of human-induced pluripotent stem cells into neural stem cells. Mol Cell Biochem 395(1-2): 291-298, 2014. PMID: 24972705. DOI: 10.1007/s11010-014-2130-3

44 Zemel'ko VI, Kozhukharova IB, Alekseenko LL, Domnina AP, Reshetnikova GF, Puzanov MV, Dmitrieva RI, Grinchuk TM, Nikol'skiı $\mathrm{NN}$ and Anisimov SV: [Neurogenic potential of human mesenchymal stem cells isolated from bone marrow, adipose tissue and endometrium: a comparative study]. Tsitologiia 55(2): 101-110, 2013. PMID: 23718072.

45 Pavlova G, Lopatina T, Kalinina N, Rybalkina E, Parfyonova Y, Tkachuk $\mathrm{V}$ and Revishchin A: In vitro neuronal induction of adipose-derived stem cells and their fate after transplantation into injured mouse brain. Curr Med Chem 19(30): 5170-5177, 2012. PMID: 22934763. DOI: 10.2174/092986712803530557

46 Romano A, Giallongo C, La Cava P, Parrinello NL, Chiechi A, Vetro C, Tibullo D, Di Raimondo F, Liotta LA, Espina V and Palumbo GA: Proteomic analysis reveals autophagy as prosurvival pathway elicited by long-term exposure with 5- azacitidine in high-risk myelodysplasia. Front Pharmacol 8: 204, 2017. PMID: 28491035. DOI: 10.3389/fphar.2017.00204

$47 \mathrm{Lu} \mathrm{Y,} \mathrm{Yuan} \mathrm{X,} \mathrm{Sun} \mathrm{Q} \mathrm{and} \mathrm{Ou} \mathrm{Y:} \mathrm{Autophagy} \mathrm{activator} \mathrm{promotes}$ neuronal differentiation of adult adipose-derived stromal cells. Neural Regen Res 8(10): 882-889, 2013. PMID: 25206379. DOI: $10.3969 /$ j.issn.1673-5374.2013.10.002

48 Zeng $\mathrm{M}$ and Zhou JN: Roles of autophagy and mTOR signaling in neuronal differentiation of mouse neuroblastoma cells. Cell Signal 20(4): 659-665, 2008. PMID: 18207367. DOI: 10.1016/ j.cellsig.2007.11.015

49 Kabeya Y, Mizushima N, Ueno T, Yamamoto A, Kirisako T, Noda T, Kominami E, Ohsumi Y and Yoshimori T: LC3, a mammalian homologue of yeast Apg8p, is localized in autophagosome membranes after processing. EMBO J 19(21): 5720-5728, 2000. PMID: 11060023. DOI: 10.1093/emboj/ 19.21.5720

50 Mizushima N, Yamamoto A, Matsui M, Yoshimori $\mathrm{T}$ and Ohsumi Y: In vivo analysis of autophagy in response to nutrient starvation using transgenic mice expressing a fluorescent autophagosome marker. Mol Biol Cell 15(3): 1101-1111, 2004. PMID: 14699058. DOI: 10.1091/mbc.e03-09-0704

51 Bankston AN, Forston MD, Howard RM, Andres KR, Smith AE, Ohri SS, Bates ML, Bunge MB and Whittemore SR: Autophagy is essential for oligodendrocyte differentiation, survival, and proper myelination. Glia 67(9): 1745-1759, 2019. PMID: 31162728. DOI: 10.1002/glia.23646

52 Ha S, Jeong S, Yi K, Chu J, Kim S, Kim E and Yu S: Autophagy mediates astrogenesis in adult hippocampal neural stem cells. Experimental Neurobiology 28(2): 229-246, 2020. DOI: 10.5607/en.2019.28.2.229

53 Vantaggiato C, Castelli M, Giovarelli M, Orso G, Bassi MT, Clementi E and De Palma C: The fine tuning of Drp1-dependent mitochondrial remodeling and autophagy controls neuronal differentiation. Front Cell Neurosci 13: 120, 2019. PMID: 31019453. DOI: $10.3389 /$ fncel.2019.00120

54 Xia Q, Zheng Y, Jiang W, Huang Z, Wang M, Rodriguez R and Jin X: Valproic acid induces autophagy by suppressing the Akt/mTOR pathway in human prostate cancer cells. Oncol Lett 12(3): 1826-1832, 2016. PMID: 27588130. DOI: 10.3892/ ol.2016.4880

55 Torgersen ML, Engedal N, Bøe SO, Hokland P and Simonsen A: Targeting autophagy potentiates the apoptotic effect of histone deacetylase inhibitors in $\mathrm{t}(8 ; 21)$ AML cells. Blood 122(14): 2467-2476, 2013. PMID: 23970379. DOI: 10.1182/ blood-2013-05-500629

56 Vukićević V, Qin N, Balyura M, Eisenhofer G, Wong ML, Licinio J, Bornstein SR and Ehrhart-Bornstein M: Valproic acid enhances neuronal differentiation of sympathoadrenal progenitor cells. Mol Psychiatry 20(8): 941-950, 2015. PMID: 25707399. DOI: $10.1038 / \mathrm{mp} .2015 .3$

57 Jeong SG, Ohn T, Kim SH and Cho GW: Valproic acid promotes neuronal differentiation by induction of neuroprogenitors in human bone-marrow mesenchymal stromal cells. Neurosci Lett 554: 22-27, 2013. PMID: 24021810. DOI: 10.1016/j.neulet. 2013.08.059

Received April 14, 2021

Revised May 30, 2021

Accepted June 1, 2021 